\title{
Soymilk plain beverages: correlation between acceptability and physical and chemical characteristics
}

Marcela Moreira TERHAAG ${ }^{1,2 \star}$, Mariana Bortholazzi ALMEIDA², Marta de Toledo BENASSI ${ }^{2}$

\begin{abstract}
The objective of the research was to relate the physical and chemical characteristics of soymilk plain beverages to its sensory acceptance. Five commercial products and a new product formulated based on the less accepted sample were used. The overall acceptance was evaluated by 102 assessors using a 10-point hybrid hedonic scale. The hedonic scores ranged from 3.8 (sample E) to 7.0 (A). Most assessors (55\%) preferred sample A, which was viscous $(26.6 \mathrm{cp})$, dark $\left(\mathrm{L}^{*}=77.7\right)$, and slightly acidic $(\mathrm{pH}=6.6)$. Sample C, which had lower solid content and higher acidity, was preferred by $29 \%$ of the assessors. These two beverages showed the greatest commercial potential of the products analyzed. The least-accepted sample (E), preferred by $8 \%$ of the assessors, had a lighter color $\left(\mathrm{L}^{*}=96.8\right)$, lower viscosity $(13.5 \mathrm{cp})$, higher lipid content $(2.2 \mathrm{~g} / 100 \mathrm{~g})$, and less protein $(1.68 \mathrm{~g} / 100 \mathrm{~g})$ than the other products evaluated. A reformulation of the least preferred product (E) with the addition of maltodextrin and also vanilla and milk flavors increased its acceptance, yielding an average score of 7.2. Overall, it was observed that a soymilk plain beverage with higher viscosity, darker color, and higher protein content best meets consumer expectations.
\end{abstract}

Keywords: viscosity; vanilla flavor; color; consumer segmentation.

\section{Introduction}

Soybean [Glicine Max (L) Merrill] is a legume of high nutritional value that originated from China and is distributed worldwide (LIU, 1997). The development of soy-based products, spurred by their nutritional profile, low cost, and good functional properties, has increasingly constituted an important part in the Western diet (ISANGA; ZHANG, 2008; MESSINA; MESSINA, 2000; POTTER et al., 2007; SHAMSUDDIN, 2002; TORRES-PENARANDA; REITMEIER, 2001).

The hydrosoluble extract of soybeans is an inexpensive, unfermented derivative with high-quality protein and energy content (WANG et al., 1997). The typical flavors of the products (related to compounds of the grain or formed during processing) are generally considered unpleasant, which is a major barrier to their direct consumption (BEHRENS; SILVA, 2004; TORRES-PENARANDA et al., 1998; TORRESPENARANDA; REITMEIER, 2001). Soy beverages can be directly obtained by aqueous extraction of the whole grain or by adding water to suspensions of isolated soy protein and soybean oil (SOYFOODS..., 2006). Differences in the raw materials used (including those due to cultivar and edaphoclimatic factors), the use of isolated protein or the whole grain, and beverage composition (including soy content and additives such as sugar, salt, oil, and flavorings) provide great diversity to the sensory profiles of soy beverages (KEAST; LAU, 2006).

Soymilk, flavored soymilk, and soy beverages containing fruit juice are available to consumers worldwide. From 1998 to 2008, sales in the U.S. market grew from 194.2 to 889.5 million liters (U.S. SOU BEVERAGE MARKET, 2009); the
Brazilian market has grown at similar rate (ASSOCIAÇÃO..., 2010). Despite this increase in consumption, the development of products that are widely accepted by consumers remains a challenge (BEHRENS; SILVA, 2004; CALLOU et al., 2010; FELBERG et al., 2009). Soy flavor not completely masked by the flavorings is still a major factor in rejection (POTTER et al., 2007). It is worth mentioning that in the Brazilian market different brand products that are described as plain soymilk have different composition and protein content thus contributing to differences in sensory characteristics (TERHAAG; BENASSI, 2011).

Internal preference mapping is a technique usually applied in consumer studies, in which a vector space is built based on acceptance data generated from affective tests (MacFIE; THOMPSON, 1988; LAWLESS; HEYMANN, 2010). Multivariate statistical techniques such as Multidimensional Scaling are employed to obtain a preference space, resulting in a set of acceptance vectors, in which each vector indicates a behavior of preference for each consumer (OLIVEIRA et al., 2004).

In the present study, the acceptance of commercial plain soymilk beverages was evaluated using an Internal Preference Mapping and their physicochemical characteristics $(\mathrm{pH}$, soluble solids, color, titratable acidity, viscosity, protein, ash, and lipid content) were correlated.

The aim of this study was to identify the well-accepted characteristics of soymilk plain beverages. The least-accepted product was reformulated in order to increase its acceptability.

\footnotetext{
Received 21/11/2012

Accepted 6/5/2013 (005947)

'Departamento Ciência e Tecnologia de Alimentos, Instituto Federal do Paraná - IFPR, Rod. PR 323, Km 310, Parque Industrial, CEP 87507-014, Umuarama, PR, Brazil,

e-mail: marcela.terhaag@ifpr.edu.br

${ }^{2}$ Departamento de Ciência e Tecnologia de Alimentos, Universidade Estadual de Londrina - UEL, CEP 86057-970, Londrina, PR, Brazil

${ }^{*}$ Corresponding author
}

DOI: http://dx.doi.org/10.1590/S0101-20612013005000052 


\section{Materials and methods}

\subsection{Materials}

The commercial products described in Table 1 were purchased from local supermarkets. The products were selected considering brands with significant domestic sales but with different ingredients. It was confirmed in a preliminary study that these beverages have diverse sensory profiles (TERHAAG; BENASSI, 2011).

The products were packed in Tetra Pak-type cartons and subjected to ultra-high temperature (UHT) treatment. The samples used in the sensory evaluations and physical and chemical analyses came from the same batches and production scheduling. All measurements were performed within the declared shelf-life period of each sample; more than two months before their expiration date. Samples were homogenized according to their packing instructions immediately prior to analysis.

Using data from the physical, chemical, and acceptance analyses, the least-accepted drink (E) was reformulated. The resulting product $\left(\mathrm{E}_{\text {modif }}\right)$ was produced in the same industrial plant used for product E, packed in Tetra Pak-type cartons, and subjected to UHT treatment using an industrial vacuum thermal instant sterilizer (VTIS) at $142{ }^{\circ} \mathrm{C}$ for $5 \mathrm{sec}$.

\subsection{Physical and chemical analyses}

Values of $\mathrm{pH}$ were measured using a $\mathrm{pH}$ meter (Qualxtron 8010, Jundiaí, Brazil) as described by AOAC (ASSOCIATION..., 1995). An Atago PAL-1P digital refractometer with automatic temperature compensation (Atago Co. Ltd., Tokyo, Japan) on a scale from 0 to $32^{\circ}$ Brix (INSTITUTO..., 1985) was used to determine the total soluble solids (TSS). The total titratable acidity was measured by titrating samples with $0.1 \mathrm{~N}$ $\mathrm{NaOH}$ solution. The results were expressed as grams of citric acid/100 mL (INSTITUTO..., 1985). Ash, protein, and lipid contents were determined according to the Adolfo Lutz Institute (INSTITUTO..., 1985). The Kjeldahl standard method with a factor of 6.25 was used to measure protein content. Lipid content was measured using the Soxhlet method; the samples were homogenized by sonication for 2 minutes prior to withdrawing sample aliquots. Viscosity was measured using a viscometer (Brookfield, model DV-II, Harlow, United Kingdom) with a \#4 spindle at $100 \mathrm{rpm}$ and $17^{\circ} \mathrm{C}$.

Sample color was measured using a digital colorimeter (Minolta CR-300, Tokyo, Japan) employing D65 illuminant and a $45 \% / 0^{\circ}$ geometry. The samples were placed in an accessory for granular products (CRA50), which was completely filled The measurement was performed using the CR-A33A SM Accessory (with glass, for liquids) in contact with the surface of the product. The lightness $\left(\mathrm{L}^{*}\right)$, red-green $\left(\mathrm{a}^{*}\right)$, and yellowblue $\left(b^{*}\right)$ components of the samples were measured, and the hue angle $\left(h^{\circ}=\arctan b^{\star} / a^{\star}\right)$ and chroma $\left(C^{\star}=\left(a^{\star 2+} b^{\star 2}\right)^{1 / 2}\right)$ were calculated.

Samples A, B, C, D, and E were analyzed using a randomized experimental design. The $\mathrm{E}_{\text {modif }}$ sample was analyzed separately. The analyses were performed in triplicate using three packages of each sample.

One-way analysis of variance (ANOVA) was used to analyze the differences between the products (A, B, C, D, and E). The mean comparison test (Tukey test, at 5\% significance level) was also used. The results were also evaluated using Principal Component Analysis (PCA) and Hierarchical Cluster Analysis (HCA). The hierarchical tree was obtained by unweighted pairgroup average as the linkage rule and considering the Euclidean distances as the coefficient of similarity. Statistical analyses were performed using the Statistica 7.0 software (STATSOFT, 2006).

\subsection{Sensory evaluation}

The tests were performed in individual booths. All tests were performed under white light except for the triangular test, which was performed under red light. The samples $(30 \mathrm{~mL})$ were served cold $\left(7 \pm 2^{\circ} \mathrm{C}\right)$ in $50 \mathrm{~mL}$ plastic cups codified with three-digit random numbers and were presented monadically for all tests. Mineral water at room temperature and saltwater biscuits were served to allow the assessors to cleanse their palates between samples.

Demographic sociological characteristics of consumers including age, gender, education, and consuming habits regarding the product in question were collected to characterize the panels. The assessors were previously informed about the products and testing procedures, as described in the project registered with the National Research Ethics System (Project \# 193/09/UEL, CAAE 0142.0.268.000-09).

\section{Acceptance tests}

Two acceptance tests were conducted.

In the first one, 102 usual or potential consumers of soy beverage products were used as assessors to build the preference mapping of the commercial samples. This group consisted of 37 men and 65 women, $86 \%$ of whom were undergraduate

Table 1. Ingredient lists of the commercial soy beverages studied.

\begin{tabular}{|c|c|}
\hline Products & Ingredients lists \\
\hline A & $\begin{array}{l}\text { Soymilk, water, sugar, salt, vitamins } \mathrm{A}, \mathrm{C}, \mathrm{D}, \mathrm{E}, \mathrm{B}_{2}, \mathrm{~B}_{6}, \mathrm{~B}_{12} \text {, folic acid and minerals (calcium and zinc), vanilla flavor (natural identical), } \\
\text { stabilizer gellan gum, sodium citrate, xanthan gum, and soy lecithin. }\end{array}$ \\
\hline $\mathrm{B}$ & $\begin{array}{l}\text { Soymilk, water, sugar, salt, stabilizers microcrystalline cellulose, carboxymethyl cellulose, carrageenan and soy lecithin, natural and to } \\
\text { natural identical flavoring, thickener carrageenan gum, vitamins }\left(\mathrm{C}, \mathrm{E}, \mathrm{B}, \mathrm{A}, \text { folic acid, D and } \mathrm{B}_{12}\right) \text {, and iron. }\end{array}$ \\
\hline $\mathrm{C}$ & Water, soymilk, sugar, salt, calcium citrate, thickener carrageenan gum, and stabilizer sodium citrate. \\
\hline $\mathrm{D}$ & Water, soymilk, sugar, salt, vitamins A and D, stabilizer carrageenan gum, and flavoring. \\
\hline $\mathrm{E}$ & $\begin{array}{l}\text { Water, sugar, soy protein isolated, soy oil, stabilizer sodium citrate, milk flavor (natural identical), salt, stabilizer carrageenan gum, and } \\
\text { vitamins A and D. }\end{array}$ \\
\hline
\end{tabular}


and graduate students. Most assessors (92\%) were young, aged between 15 and 35, and 64\% hold a university degree or higher. The assessors reported average consumptions of 3.58 liters of soy beverage per month. This level of consumption is higher than the Brazilian average level, which was 2.80 liters of soy beverage per month in 2007, according to ABIR (ASSOCIAÇÃO..., 2011).

Each consumer evaluated the five samples (A, B, C, D, and $\mathrm{E}$ ) in a single session, following an experimental design of complete balanced and randomized blocks. A 10-point hybrid hedonic scale anchored with verbal terms at the extremes (VILLANUEVA; PETENATE; DA SILVA, 2005) was used to evaluate overall acceptance. The consumers were asked to specify the most and least appreciated characteristics in each sample.

The second acceptance evaluation was performed to test the overall acceptance of the $\mathrm{E}_{\text {modif }}$ sample. Each consumer evaluated the sample $\left(\mathrm{E}_{\text {modif }}\right)$ using the same scale described above, and they were also asked to specify the most and least appreciated characteristics in the sample. The demographic profile of this panel (101 assessors, 54 men and 47 women) was similar to that of the assessors used in Preference mapping: 80\% were aged between 15 and 35 years, 91\% were students attending technical, undergraduate or graduate school (91\%), and most had completed high school (46\%) or higher (48\%). The group consumed an average 2.57 liters of soy beverages per month.

\section{Discriminative test}

Sensory differences between $\mathrm{E}$ and $\mathrm{E}_{\text {modif }}$ samples were evaluated with a triangular test using 27 assessors. The samples were presented following a complete balanced block design.

\section{Sensory data analysis}

For the comparison of the acceptance of commercial samples, a two-way analysis of variance (ANOVA), in which sample and consumer were the sources of variation, was applied to the data. Significance of differences between samples was determined by the Tukey test (at $5 \%$ significance level). Internal preference mapping was obtained for the overall acceptability data matrix by SENSTOOLS 2.3.28 software package (OP\&P PRODUCT RESEARCH, 1995-1998). The preference space was defined using the Multidimensional Scaling technique associated with Hierarchical Cluster Analysis (OLIVEIRA et al., 2004).

The results of the triangular test were evaluated by the chisquare test (STONE; SIDEL, 2003) at a 5\% significance level.

\section{Results and discussion}

\subsection{Physical and chemical characterization of the commercial products}

The beverages differed in terms of lipid, protein, and ash content, titratable acidity, $\mathrm{pH}$ values, TSS value, viscosity, and color parameters $\left(\mathrm{L}^{*}, \mathrm{a}^{*}, \mathrm{~b}^{*}, \mathrm{C}^{*}\right.$, and $\left.\mathrm{h}^{\circ}\right)$ (Table 2). TSS values ranged from 8.1 to $10.10^{\circ} \mathrm{Brix}$, lower than those reported by Villegas, Carbonell and Costell (2011) for Spanish vanillaflavored soy beverages ( 10.5 to $\left.18.3^{\circ} \mathrm{Brix}\right)$. Callou et al. (2010) reported higher protein contents for soy beverages commercialized in the Brazilian market.

PCA and HCA were used to assess the importance of these variables in the discrimination of the samples. The first two Principal Components (PCs) accounted for $84 \%$ of the data variance (Figure 1). The commercial soy beverages that were similar in one or more characteristics were close together as shown in Figure 1a and were grouped by HCA (Figure 1c). Figure $1 \mathrm{~b}$ shows the variable vectors.

PC1 was negatively correlated with protein content, titratable acidity, viscosity, and $\mathrm{C}^{\star}$ and positively correlated with lipid content and $\mathrm{L}^{*}$. PC 2 was positively correlated with $\mathrm{pH}$ and ash content. Samples A and E differed the most from the others (Figure 1).

Sample E, located in quadrant IV, had a light and relatively unsaturated color (with $L^{\star}$ of 96.8 and $C^{\star}$ of 8.3), low viscosity

Table 2. Physical and chemical characterization ${ }^{1}$ and acceptance ${ }^{2}$ of the soymilk plain commercials beverages.

\begin{tabular}{|c|c|c|c|c|c|c|c|}
\hline \multicolumn{3}{|c|}{ Parameters } & A & $\mathrm{B}$ & $\mathrm{C}$ & $\mathrm{D}$ & $\mathrm{E}$ \\
\hline \multicolumn{3}{|c|}{ Lipids (\%) } & $1.65 \pm 0.09^{b c}$ & $1.71 \pm 0.03^{\mathrm{b}}$ & $1.35 \pm 0.02^{\mathrm{d}}$ & $1.52 \pm 0.05^{c}$ & $2.17 \pm 0.04^{\mathrm{a}}$ \\
\hline \multirow{11}{*}{$\begin{array}{l}\text { Physical and } \\
\text { chemical } \\
\text { characteristics }\end{array}$} & \multicolumn{2}{|c|}{ Protein (\%) } & $2.36 \pm 0.03^{\mathrm{a}}$ & $2.30 \pm 0.02^{\mathrm{a}}$ & $2.01 \pm 0.01^{\mathrm{b}}$ & $2.34 \pm 0.01^{\mathrm{a}}$ & $1.68 \pm 0.04^{\mathrm{c}}$ \\
\hline & \multicolumn{2}{|c|}{ Ash (\%) } & $0.62 \pm 0.03^{\mathrm{a}}$ & $0.44 \pm 0.01^{\mathrm{c}}$ & $0.42 \pm 0.04^{c}$ & $0.51 \pm 0.02^{\mathrm{b}}$ & $0.43 \pm 0.02^{c}$ \\
\hline & \multicolumn{2}{|c|}{ TA (g citric acid/100 g) } & $0.058 \pm 0.000^{c}$ & $0.077 \pm 0.000^{\mathrm{a}}$ & $0.077 \pm 0.000^{\mathrm{a}}$ & $0.070 \pm 0.000^{\mathrm{b}}$ & $0.032 \pm 0.000^{\mathrm{d}}$ \\
\hline & \multicolumn{2}{|l|}{$\mathrm{pH}$} & $7.02 \pm 0.01^{\mathrm{a}}$ & $6.70 \pm 0.00^{\mathrm{d}}$ & $6.61 \pm 0.01^{\mathrm{e}}$ & $6.76 \pm 0.01^{\mathrm{c}}$ & $6.79 \pm 0.00^{\mathrm{b}}$ \\
\hline & \multicolumn{2}{|c|}{ TSS ( ${ }^{\circ}$ Brix) } & $8.80 \pm 0.00^{c}$ & $10.10 \pm 0.00^{\mathrm{a}}$ & $8.10 \pm 0.00^{\mathrm{d}}$ & $10.10 \pm 0.00^{\mathrm{a}}$ & $10.00 \pm 0.00^{\mathrm{b}}$ \\
\hline & \multicolumn{2}{|c|}{ Viscosity (cp) } & $26.6 \pm 0.0^{\mathrm{a}}$ & $18.40 \pm 0.00^{c}$ & $15.80 \pm 0.00^{\mathrm{d}}$ & $23.40 \pm 0.00^{\mathrm{b}}$ & $13.50 \pm 0.00^{\mathrm{e}}$ \\
\hline & \multirow{5}{*}{ Color } & $\mathrm{L}^{*}$ & $77.7 \pm 0.9^{c}$ & $79.2 \pm 1.4^{\mathrm{c}}$ & $86.2 \pm 1.3^{\mathrm{b}}$ & $84.8 \pm 0.9^{b}$ & $96.8 \pm 1.5^{\mathrm{a}}$ \\
\hline & & $a^{*}$ & $1.8 \pm 0.1^{\mathrm{b}}$ & $2.6 \pm 0.3^{\mathrm{a}}$ & $1.4 \pm 0.2^{b c}$ & $2.8 \pm 0.1^{\mathrm{a}}$ & $1.0 \pm 0.1^{c}$ \\
\hline & & $\mathrm{b}^{*}$ & $15.7 \pm 0.1^{\mathrm{b}}$ & $16.3 \pm 0.3^{\mathrm{b}}$ & $14.5 \pm 0.3^{c}$ & $16.9 \pm 0.2^{\mathrm{a}}$ & $8.2 \pm 0.2^{\mathrm{d}}$ \\
\hline & & $\mathrm{h}^{\circ}$ & $83.5 \pm 0.4^{\mathrm{a}}$ & $80.9 \pm 0.8^{b}$ & $84.3 \pm 0.8^{\mathrm{a}}$ & $80.8 \pm 0.2^{b}$ & $83.1 \pm 0.9^{a}$ \\
\hline & & $\mathrm{C}^{\star}$ & $15.9 \pm 0.1^{\mathrm{b}}$ & $16.5 \pm 0.4^{b}$ & $14.6 \pm 0.3^{c}$ & $17.2 \pm 0.2^{\mathrm{a}}$ & $8.3 \pm 0.2^{\mathrm{d}}$ \\
\hline \multirow{2}{*}{ Acceptance } & \multicolumn{2}{|c|}{ Hedonic score ${ }^{2}$} & $7.0^{\mathrm{a}}$ & $5.5^{\mathrm{b}}$ & $5.7^{\mathrm{b}}$ & $5.9^{\mathrm{b}}$ & $3.8^{\mathrm{c}}$ \\
\hline & \multicolumn{2}{|c|}{$\%$ Approval $^{3}$} & 87 & 68 & 68 & 73 & 36 \\
\hline
\end{tabular}

${ }^{1}$ Mean \pm SD (three analyses); ${ }^{2}$ Mean of 102 assessors $\left(0=\right.$ disliked extremely, $10=$ liked extremely); ${ }^{3} \%$ approval: percentage of scores equal to or greater than 5 . TA: titratable acidity,

TSS: total soluble solids. Different letters in the same row indicate significant differences $(\mathrm{p}<0.05)$. 

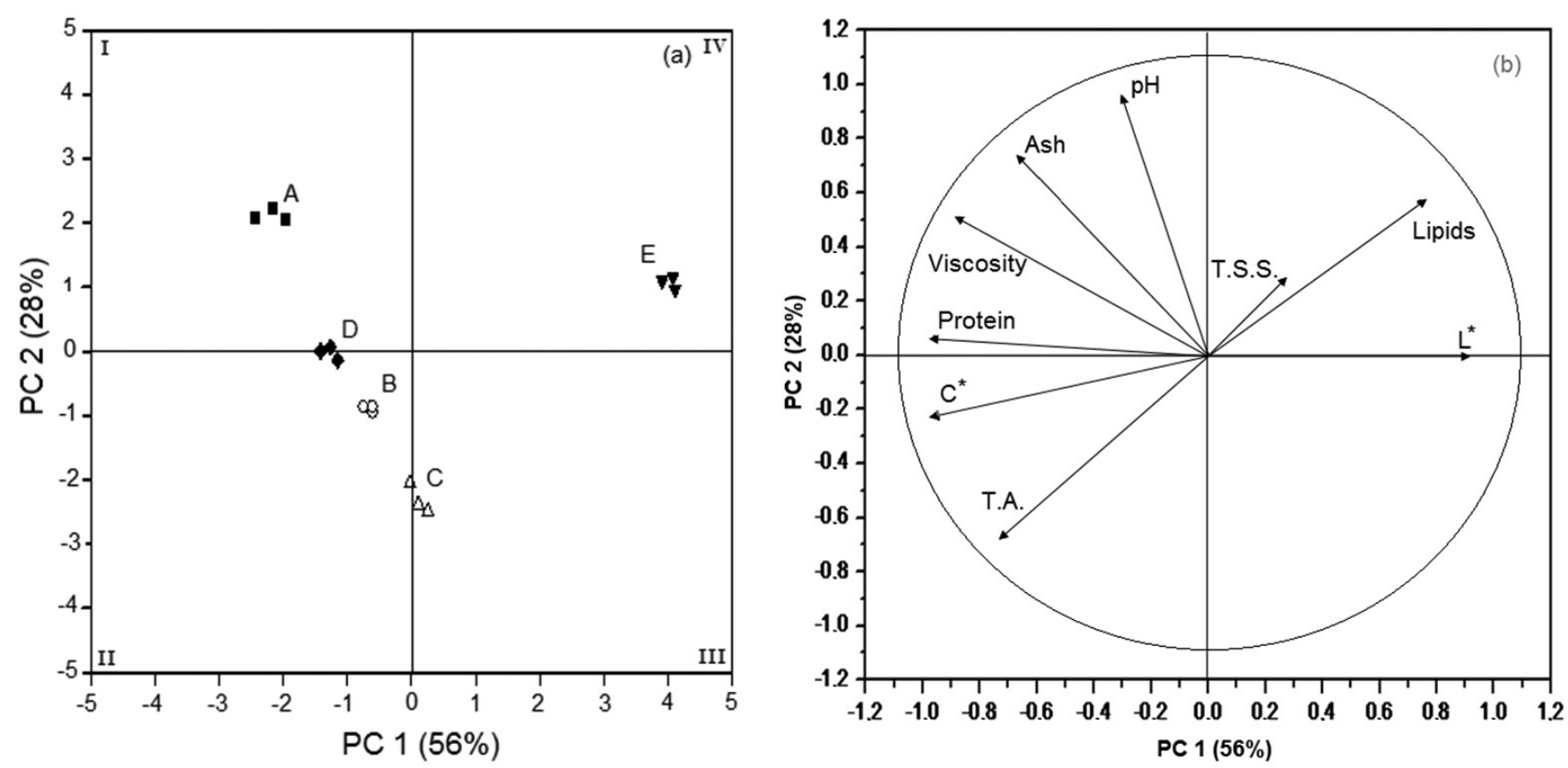

(c)

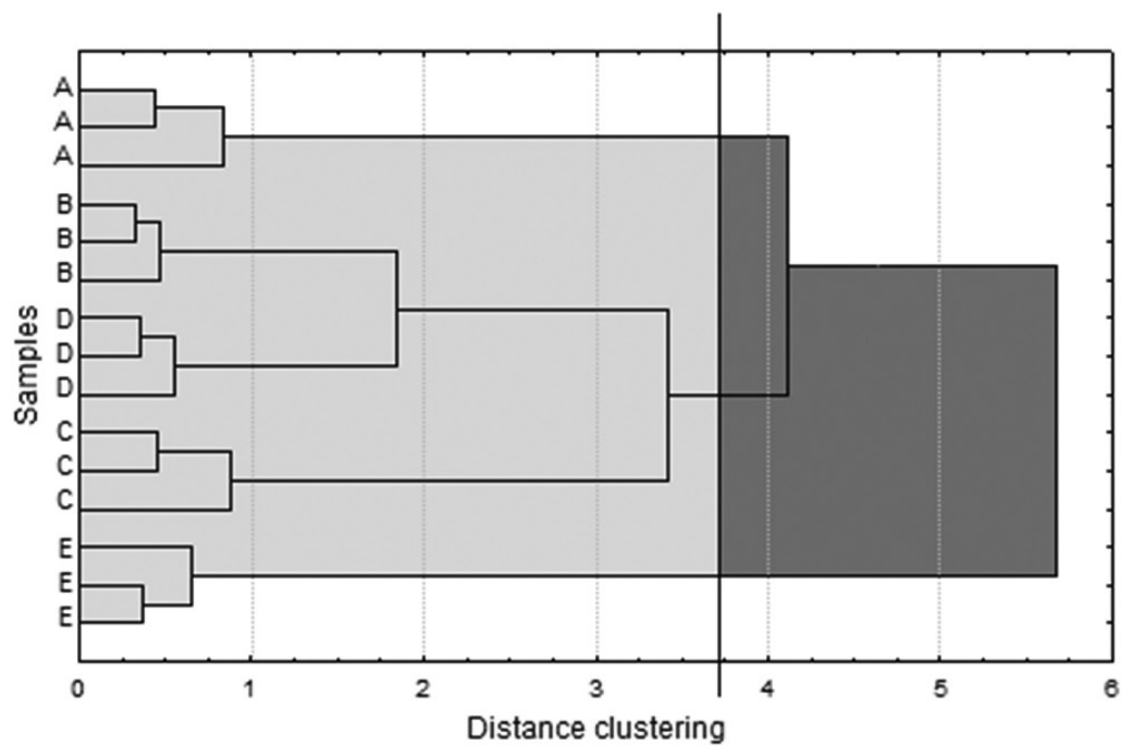

Figure 1. Projection of variables (a) and scatter plot of the samples (b) by Principal Component Analysis and dendrogram obtained by Hierarchical Cluster Analysis (c) considering the physical and chemical characteristics of soymilk plain commercials beverages (letters A to E). TA: titratable acidity, TSS: total soluble solids.

(13.4 cp), low acidity (0.032 g citric acid/100 g), high lipid content $(2.17 \mathrm{~g} / 100 \mathrm{~g})$, and low protein content $(1.68 \mathrm{~g} / 100 \mathrm{~g})$ (Figure 1 and Table 2). In contrast, sample A (quadrant I) stood out for its high viscosity $(26.5 \mathrm{cp})$ and ash content $(0.62 \mathrm{~g} / 100 \mathrm{~g})$. Sample A also had high protein content $(2.36 \mathrm{~g} / 100 \mathrm{~g})$, low TSS (8.80 ${ }^{\circ}$ Brix), and dark color ( $L^{*}$ of 77.7 ) (Figure 1 and Table 2 ).

Samples B, C, and D (located in quadrant II and III) were characterized as similar by PCA and grouped by HCA (Figure 1), but they could be distinguished by their lipid content, viscosity, $\mathrm{pH}$ value, and color (parameters $\mathrm{b}^{\star}$ and $\mathrm{C}^{\star}$ ) (Table 2 ).

\subsection{Acceptance of commercial beverages}

The commercial beverages received average scores between 7.0 and 3.8 (Table 2). High rates of approval, defined as scores of 5 or above, were observed for all sample, except for beverage E (36\%). Product A received approval from $87 \%$ of assessors, and products $\mathrm{B}, \mathrm{C}$, and $\mathrm{D}$ had a medium performance, with approvals close to $70 \%$ (Table 2). It is important to highlight that the assessors were regular consumers of the products tested (item 2.3).

The acceptance values in this study were higher than those reported by Villegas, Carbonell and Costell (2011) for 
vanilla-flavored soy beverages (between 3.4 and 4.0 on a 9-point scale). However, it must be considered that the soy beverages were evaluated together with vanilla-flavored milk drinks. Considering those who consume only soymilk, the authors reported significantly higher acceptability values to this type of beverage (4.0 to 5.3).

The overall acceptance data correlated well with the physical and chemical profile of the samples (Figure 1). Samples A and E, with very different physical and chemical characteristics, had the greatest and least acceptances, respectively. Samples $\mathrm{B}, \mathrm{C}$, and D, which were grouped according to their physical and chemical characteristics (Figure 1), had similar acceptance scores (5.5 to 5.9) (Table 2).

For a more comprehensive evaluation, the results were also analyzed using the Internal Preference Mapping (Figure 2). The proportion of variance explained by the first two dimensions was $68 \%$.

Most of the participants (56 assessors, 55\%) preferred sample A, which can be found left-hand side of the map (Group 1) (Figure 2). The most frequently desirable characteristics of this sample were flavor, viscosity, and sweetness (34, 17, and $13 \%$ of responses, respectively) (Table 3 ). Sample A had low lipid content and TSS value and higher apparent viscosity (Figure 1). The most frequently negative characteristic reported for this sample was its color (22\%, Table 3$)$, indicating that the darker color of the product was not appreciated (Table 2). When asked to name a negative characteristic of the beverage, fourteen percent of the respondents used the word "nothing", explaining its high rate of acceptance (Table 2).

Beverages B, C, and D did not differ in acceptance (Table 2) and had similar physical and chemical characteristics (Figure 1). Two groups of consumers were segmented: one group that preferred sample B (8 individuals, Group 2) and the other that preferred sample C (30 individuals, Group 3) (Figure 2, Table 4). Sample D was allocated between these two groupsand was not preferred by any consumer.
Sample E was preferred by only $8 \%$ of the assessors (Group 4) (Table 4). Its average overall acceptance score was 3.8 (Table 3), which was the lowest among all beverages evaluated. It was significantly less accepted by assessors in Groups 1 and 3 ( $84 \%$ of the panel) (Table 4 ). The most frequently negative characteristics reported were its flavor, color, and salty taste (70, 25 and 17\%) (Table 3). The large number of negative characteristics reported (\% of responses of the least appreciated characteristics) for sample E justifies its separation from the other beverages studied.

Descriptions of beverages as "watery" were included only in lists of undesirable characteristics, indicating a preference for viscous beverages. Sample A, characterized by a higher viscosity, was described as "watery" in $17 \%$ of responses, less than that of samples B, C, and D (23, 41 and $21 \%$, respectively) (Tables 2 and 3).

Despite the emphasis in the literature placed on the rejection of soy beverages due to flavor (TORRES-PENARANDA; REITMEIER, 2001; TORRES-PENARANDA et al., 1998; POTTER et al., 2007; BEHRENS; SILVA, 2004), the aftertaste was reported as the least desirable characteristic (20 and 11\% of cases, respectively) only for beverages B and C (Table 3 ). The attribute flavor was mainly reported as positive for beverages A, B, C, and D. Flavor was reported as a negative characteristic only for sample E (70 and 17\% reported its flavor and salty taste, respectively) (Table 3 ).

According to the beverage ingredients (Table 1), sample E contained milk flavor (nature-identical) and different from the vanilla flavor listed for sample A. In a previous study with descriptive evaluations of these products, Terhaag and Benassi (2011) reported that beverage E was described as having a slightly salty characteristic flavor, as opposed to drink A, which had a characteristic vanilla and sweet flavor. Considering the familiarity of the consumers with the product, the high number negative reports about its taste could be attributed to the use of milk flavor and/or lack of vanilla flavoring.

Table 3. Most appreciated and least appreciated sensory characteristics of each beverage and frequency of reporting (\%).

\begin{tabular}{|c|c|c|c|c|}
\hline Beverage $^{1}$ & Most appreciated & $\%$ of reporting ${ }^{2}$ & Least appreciated & $\%$ of reporting ${ }^{2}$ \\
\hline \multirow[t]{3}{*}{ A } & Flavor & 34 & Color & 22 \\
\hline & Viscosity & 17 & Watery & 17 \\
\hline & Sweetness & 13 & "Nothing" & 14 \\
\hline \multirow[t]{3}{*}{ B } & Color & 30 & Flavor & 26 \\
\hline & Aroma & 16 & Watery & 23 \\
\hline & Flavor & 15 & Aftertaste & 20 \\
\hline \multirow[t]{3}{*}{$\mathrm{C}$} & Flavor & 42 & Watery & 41 \\
\hline & Sweetness & 18 & Flavor & 22 \\
\hline & Aroma & 17 & Aftertaste & 11 \\
\hline \multirow[t]{3}{*}{$\mathrm{D}$} & Flavor & 39 & Flavor & 25 \\
\hline & Color & 15 & Watery & 21 \\
\hline & Aroma & 13 & Low sweetness & 13 \\
\hline \multirow[t]{3}{*}{$\mathrm{E}$} & Color & 29 & Flavor & 70 \\
\hline & Viscosity & 19 & Color & 25 \\
\hline & Sweetness & 16 & Salty taste & 17 \\
\hline
\end{tabular}

${ }^{1}$ Beverage A: preferred by the Group A; beverages B and D: preferred by the Group 2; beverage C: preferred by the Group 3; beverage E: preferred by the Group 4. ${ }^{2}$ Frequency considering the percentage of total responses for each item. 


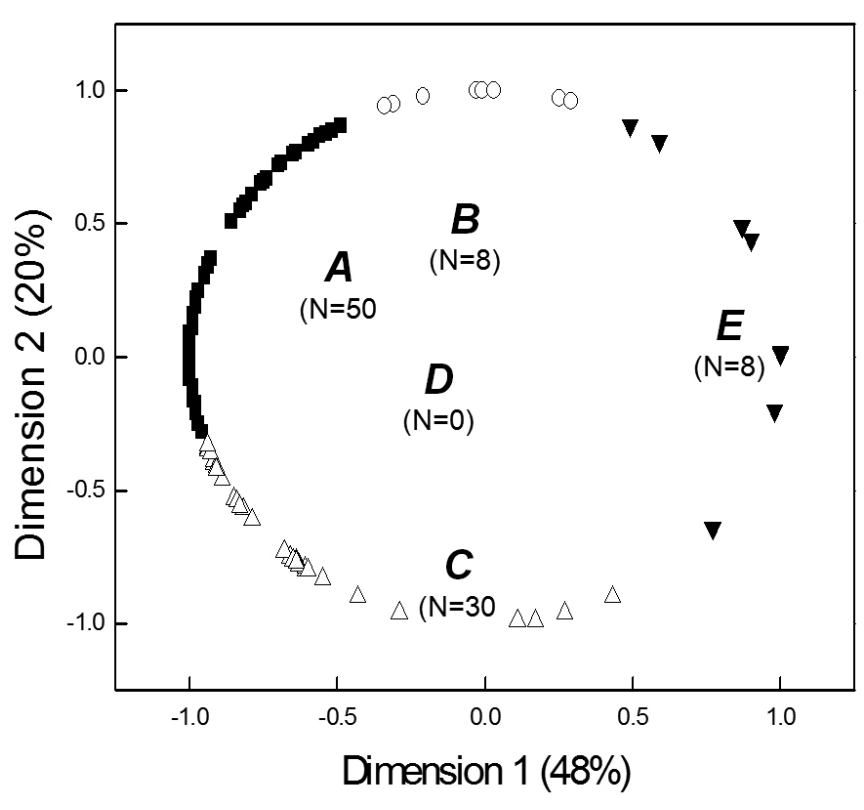

Figure 2. Internal Preference Mapping of the soymilk plain commercials beverages: configuration of the samples (letters A to E) and assessors. Each group of assessors was represented by symbols: Group $1(\mathbf{\square})$, Group $2(\circ)$, Group $3(\Delta)$ and Group $4(\boldsymbol{\Delta})$.

Table 4. Acceptance of the soymilk plain commercials beverages considering the groups of the Internal Preference Mapping.

\begin{tabular}{ccccc}
\hline \multirow{2}{*}{ Assessors/ Samples ${ }^{1}$} & \multicolumn{4}{c}{ Groups } \\
\cline { 2 - 5 } & 1 & 2 & 3 & 4 \\
\hline Number of assessors & 56 & 8 & 30 & 8 \\
A & $7.2^{\mathrm{a}}$ & $7.3^{\mathrm{a}}$ & $6.7^{\mathrm{a}}$ & $7.2^{\mathrm{a}}$ \\
B & $5.6^{\mathrm{b}}$ & $6.3^{\mathrm{a}}$ & $5.3^{\mathrm{a}}$ & $5.4^{\mathrm{a}}$ \\
C & $5.4^{\mathrm{b}}$ & $5.0^{\mathrm{a}}$ & $6.7^{\mathrm{a}}$ & $4.4^{\mathrm{a}}$ \\
D & $5.9^{\mathrm{b}}$ & $6.1^{\mathrm{a}}$ & $5.6^{\mathrm{a}}$ & $6.3^{\mathrm{a}}$ \\
E & $3.5^{\mathrm{c}}$ & $5.7^{\mathrm{a}}$ & $3.4^{\mathrm{b}}$ & $5.0^{\mathrm{a}}$ \\
\hline
\end{tabular}

${ }^{1}$ Different letters in the same column indicate significant difference $(\mathrm{p} \leq 0.05)(0=$ disliked extremely, 10 = liked extremely).
The characteristics of the each group of consumers segmented by the Preference mapping are presented in Table 5 . Group 2 consisted mainly of women (87.5\%), and Group 3 stood out as the group with highest age (53.3\% over 25), level of education (73.3\% with higher education), and soy beverage consumption habit (4.2 liters per month). Consumers in Group 4, who preferred sample E, were less educated (50\% with secondary education) and less familiarized with this type of beverage ( 2.8 liters per month) than the other participants.

In general, two of the tested products have the highest apparent commercial potentials: beverage $\mathrm{A}$, accepted by all groups, and beverage $\mathrm{C}$, which, despite having acceptance rates similar to those of $B$ and $D$, was preferred by a significant number of assessors (30\%, Group 3) who consumed more soy beverage on average than the participants in other groups (Tables 4 and 5). The two products differ mainly in viscosity and color: sample $\mathrm{C}$ was less viscous (more "watery") and lighter than A (Table 2, Figure 2). Consumers in both groups (1 and 3, $84 \%$ of the participants) disliked sample E (Table 4 ).

To further probe the effect of the physical and chemical characteristics of soy beverages on acceptance, product $\mathrm{E}$ was modified to obtain similar characteristics to those of the preferred samples: higher viscosity, darker color, higher protein content, and vanilla flavor. The desirability of some of these properties has been previously reported. The addition of carboxymethyl cellulose, which decreases perception of astringent aftertaste (COURREGELONGUE; SCHLICH; NOBLE, 1999), and flavorings such as vanilla have been reported to improve the overall acceptability of soy beverages (NTI; LARWEH, 2003; VILLEGAS; CARBONELL; COSTELL, 2011).

\subsection{Formulation and sensory evaluation of the modified sample $\left(E_{\text {modif }}\right)$}

The least-accepted product (E) was modified to produce a new beverage, " $\mathrm{E}_{\text {modif }}$ ". The ingredients of formulation $\mathrm{E}_{\text {modif }}$ (\%w/w) were: carrageenan gum (LAC 8175-5, Globalfood, São Paulo, Brazil), 0.50\%; maltodextrin (Loremalt 2002B, Cia

Table 5. Demographic data of consumers by group (expressed in percentage).

\begin{tabular}{|c|c|c|c|c|c|}
\hline \multirow{2}{*}{ Characteristic } & \multirow{2}{*}{ Description } & \multicolumn{4}{|c|}{ Group } \\
\hline & & 1 & 2 & 3 & 4 \\
\hline \multirow[t]{2}{*}{ Gender } & Male & 37.5 & 12.5 & 40.0 & 37.5 \\
\hline & Female & 62.5 & 87.5 & 60.0 & 62.5 \\
\hline \multirow[t]{4}{*}{ Age range } & $15-25$ & 66.1 & 75.0 & 46.7 & 62.5 \\
\hline & $25-35$ & 21.4 & 25.0 & 53.3 & 25.0 \\
\hline & $35-50$ & 12.5 & 0.0 & 0.0 & 0.0 \\
\hline & above 50 & 0.0 & 0.0 & 0.0 & 12.5 \\
\hline \multirow[t]{4}{*}{ Occupation } & Student & 85.7 & 87.5 & 90.0 & 75.0 \\
\hline & Employee & 3.6 & 12.5 & 6.7 & 12.5 \\
\hline & Professor & 8.9 & 0.0 & 3.3 & 0.0 \\
\hline & Other & 1.8 & 0.0 & 0.0 & 12.5 \\
\hline \multirow[t]{2}{*}{ Educational level } & College educated & 39.3 & 37.5 & 26.7 & 50.0 \\
\hline & Graduate degree & 60.7 & 62.5 & 73.3 & 50.0 \\
\hline \multicolumn{2}{|c|}{ Beverage consumption (liters/month) } & 3.4 & 3.6 & 4.2 & 2.8 \\
\hline
\end{tabular}


Lorenz, Cianorte, Brazil), 2.00\%; sugar (COSAN, Tarumã, Brazil), 3.20\%; soy protein isolate (protein level: $91 \%$, SunGreen, Nantong, China), 2.00\%; sodium chloride (Moc, Mossoró, Brazil), 0.08\%; sodium citrate (Cargill, Mairinque, Brazil), 0.10\%; soy oil (ADM, Campo Grande, Brazil), 1.80\%; vanilla flavor (natural identical number 3554331, I.F.F. Essências e Fragrâncias Ltda, Santana de Parnaiba, Brazil), 0.07\%; milk flavor (natural identical, soy masking number 79.CE2570-67, Duas Rodas Industrial, Jaraguá do Sul, Brazil), 0.30\%; milk flavor (identical to natural number 8547518-5, Duas Rodas Industrial, Jaraguá do Sul, Brazil), 0.07\%; and water (Sanepar, Brazil), $89.86 \%$.

Since the same industrial plant and process conditions were used in the production of $\mathrm{E}$ and " $\mathrm{E}_{\text {modif }}$ ", it can be proposed that any change in the product was due to the formulation and not to the process.

A combination of vanilla natural and soy-masking flavors partially replaced the milk flavor of sample E. Maltodextrin was also added as a source of soluble solids to increase viscosity. The modified beverage had higher lipid $(2.53 \mathrm{~g} / 100 \mathrm{~g})$ and protein $(1.76 \mathrm{~g} / 100 \mathrm{~g})$ content, higher $\mathrm{pH}(7.12)$ and viscosity $(16.3 \mathrm{cp})$, and lower $L^{*}(78 ; 2)$ than sample $E$. $\mathrm{E}_{\text {modif }}$ had ash content of $0.22 \mathrm{~g} / 100 \mathrm{~g}$, TSS of $9.51^{\circ} \mathrm{Brix}$, titratable acidity of $0.038 \mathrm{~g}$ of citric acid/100 g, h ${ }^{\circ}$ of 90.0 , and $\mathrm{C}^{\star}$ of 7.4.

Beverages $\mathrm{E}$ and $\mathrm{E}_{\text {modif }}$ were considered sensorially different at the $5 \%$ significance level by the triangular test (26 correct answers).

The beverage $\mathrm{E}_{\text {modif }}$ received an average score of 7.2 and $84 \%$ approval, indicating that the changes in the formulation increased product acceptance. The consumers reported its aroma, flavor, and sweetness $(28,44$ and $13 \%$ of responses, respectively) as its most desirable characteristics. "Watery" texture, aftertaste, and flavor $(26,24$, and $16 \%$ of responses, respectively) were reported as its least desirable characteristics. There was a decrease in the number of negative characteristics reported and a lower number of responses reporting "flavor" as a negative attribute of the modified sample $\left(16 \%\right.$ for $\mathrm{E}_{\text {modif }}$ against $70 \%$ for $\mathrm{E}$, Table 3 ).

This result confirms that the presence of vanilla aroma and flavor, darker color, and higher viscosity are important attributes in the acceptance of soymilk plain beverages. Villegas, Carbonell and Costell (2011) have also suggested that it is possible to increase the acceptability of vanilla-flavored soy beverages by increasing their sweetness, viscosity, and intensity of vanilla flavor.

\section{Conclusion}

The commercial soymilk plain products investigated differed in acceptance (hedonic scores ranging from 3.8 to 7.0), and two beverages showed a greater market potential. The reformulation of the least-accepted product (light color, less sticky, less acidic, and higher fat content) using vanilla and milk flavors and maltodextrin contributed to its increased acceptance. Overall, a soymilk plain beverage with higher viscosity, darker color, vanilla flavor, and higher protein content best meets consumer expectations.

\section{References}

ASSOCIAÇÃO BRASILEIRA DE INDÚSTRIAS DE REFRIGERANTE - ABIR. Brasil Relatório 2008 - Consumo de todas as bebidas comerciais 2005-2010 (2011). Disponível em: <http://abir.org.br/wp-content/plugins/download-monitor/ download.php?id=322>. Acesso em: 29 abr. 2013.

ASSOCIAÇÃO BRASILEIRA DE SUPERMERCADOS - ABRAS. Bebida de soja cai no gosto do Brasil e vende $\mathrm{R} \$ 1$ bi. (2010). Disponível em: <http://www.abras.com.br/clipping. php?area=10\&clipping=15647>. Acesso em: 29 abr. 2013.

ASSOCIATION OF OFFICIAL ANALYTICAL CHEMISTS - AOAC. Official methods of analysis. 16. ed. Arlington: AOAC International, 1995.

BEHRENS, J. H.; SILVA, M. A. A. P. Atitude do consumidor em relação à soja e produtos derivados. Ciência e Tecnologia de Alimentos, v. 24 , n. 3, p. 431-439, 2004. http://dx.doi.org/10.1590/S010120612004000300023

CALLOU, K. R. A. et al. Isoflavones and antioxidant capacity of commercial soy-based beverages: effect of storage. Journal of Agricultural and Food Chemistry, v. 58, p. 4284-4291, 2010. PMid:20199084. http://dx.doi.org/10.1021/jf904130z

COURREGELONGUE, S.; SCHLICH, P.; NOBLE, A. Using repeated ingestion to determine the effect of sweetness, viscosity and oiliness on temporal perception of soymilk astringency. Food Quality and Preference, v. 10, n. 4-5, p. 273-279, 1999. http://dx.doi.org/10.1016/ S0950-3293(98)00055-X

FELBERG, I. et al. Soy and Brazil nut beverage: processing, composition, sensory, and color evaluation. Ciência e Tecnologia de Alimentos, v. 29, n. 3, p. 609-617, 2009. http://dx.doi.org/10.1590/ S0101-20612009000300024

INSTITUTO ADOLFO LUTZ - IAL. Normas analíticas do Instituto Adolfo Lutz: métodos químicos e físicos para análise de alimentos. 3. ed. São Paulo: IAL, 1985. v. 1, 533 p.

ISANGA, J.; ZHANG, G. N. Soybean bioactive components and their implications to health - A Review. Food Reviews International, v. 24 , n. 2, p. 252-276, 2008. http://dx.doi. org/10.1080/87559120801926351

KEAST, R. S. J.; LAU, J. J. Culture-specific variation in the flavor profile of soymilks. Journal of Food Science, v. 71, n. 8, p. 567-572, 2006 http://dx.doi.org/10.1111/j.1750-3841.2006.00146.x

LAWLESS, H. T.; HEYMANN, H. Sensory evaluation of food: Principles and Practices. New York: Springer, 2010. 850 p. http:// dx.doi.org/10.1007/978-1-4419-6488-5

LIU, K. Soybeans: chemistry, technology and utilization. New York: Chapman and Hall, 1997. 532 p. http://dx.doi.org/10.1007/978-14615-1763-4

MacFIE, H. J. H.; THOMSON, D. M. H. Preference mapping and multidimensional scaling. In: PIGGOTT, J. R. (Ed.). Sensory Analysis of Food. 2. ed. New York: Elsevier, 1988. 389 p.

MESSINA, M.; MESSINA, V. Soy foods, soybean isoflavones, and bone health: a brief overview. Journal of Renal Nutrition, v. 10, n. 2, p. 63-68, 2000. http://dx.doi.org/10.1016/S1051-2276(00)90001-3

NTI, C. A.; LARWEH, P. M. Production and sensory characteristics of flavoured soymilk samples. International Journal of Consumer Studies, v. 27, n. 3, p. 181-184, 2003. http://dx.doi.org/10.1046/ j.1470-6431.2003.00305.x 
OLIVEIRA, A. P. V. et al. Aceitação de sobremesas lácteas dietéticas e formuladas com açúcar: teste afetivo e Mapa de Preferência interno. Ciência e Tecnologia Alimentos, v. 24, n. 4, p. 627-633, 2004. http:// dx.doi.org/10.1590/S0101-20612004000400025

OP \& P PRODUCT RESEARCH. Senstools Versão 2.3. Utrecht: OP \& P Product Research, 1995-1998. Conjunto de Programas. 1 CD-ROOM.

POTTER, R. M. et al. Characteristics of wild blueberry-soy beverages. LWT - Food Science and Technology, v. 40, n. 5, p. 807-814, 2007.

SOYFOODS ASSOCIATION OF AMERICA - SANA. Voluntary Standards for the Composition and Labeling of Soymilk in the United States. Disponível em: <http://www.soyfoods.org/wp/ wp-content/uploads/2006/11/smstandards.pdf>. Acesso em: 29 abr. 2013.

SHAMSUDDIN, A. M. Anti-cancer function of phytic acid. International Journal of Food Science and Technology, v. 37, n. 7, p. 769-782, 2002. http://dx.doi.org/10.1046/j.13652621.2002.00620.x

STATSOFT. STATISTICA for Windows: computer program manual. versão 7.1. Tulsa: Software Inc., 2006.

STONE, H.; SIDEL, J. L. Sensory Evaluation Practices. London: Academic Press, Inc., 2003. 311 p.

TERHAAG, M.; BENASSI, M. T. Perfil Flash: uma opção para análise descritiva rápida. Brazilian Journal of Food Technology, v. 14, p.140-151, 2011. http://dx.doi.org/10.4260/BJFT201114E000117
TORRES-PENARANDA, A. V.; REITMEIER, C. A. Sensory descriptive analysis of soymilk. Journal of Food Science, v. 66, n. 2, p. 352-356, 2001. http://dx.doi.org/10.1111/j.1365-2621.2001. tb11345.x

TORRES-PENARANDA, A. V. et al. Sensory characteristics of soymilk from lipoxygenase-free and normal soybeans. Journal of Food Science, v. 63, n. 6, p. 1084-1087, 1998. http://dx.doi. org/10.1111/j.1365-2621.1998.tb15860.x

US SOY BEVERAGE MARKET. US Health \& Wellness Market. Beverage World, v. 128, n. 9, p. 20, 2009.

VILLEGAS, B.; CARBONELL, I.; COSTELL, E. Acceptability of milk and soymilk vanilla beverages. Demographics consumption frequency and sensory aspects. Food Science and Technology International, v. 15, n. 2, p. 203-210, 2009. http://dx.doi. org/10.1177/1082013208105166

VIllanueVA, N. D. M.; PETENATE, A. J.; DA SilVA, M. A. A. P. Performance of hybrid hedonic scale as compared to the traditional hedonic, self-adjusting and ranking scales. Food Quality and Preference, v. 16, n. 8, p. 691-703, 2005. http://dx.doi.org/10.1016/j. foodqual.2005.03.013

WANG, Z. H. et al. Solid phase extraction for CG analysis of beany flavours in soymilk. Food Research International, v. 30, n. 7, p. 503-511, 1997. http://dx.doi.org/10.1016/S0963-9969(98)00006-4 